\title{
Opinia krytyczna do przeważającego poglądu reprezentowanego w orzecznictwie sądowym w zakresie ustalania dochodu z wydzierżawionego gospodarstwa rolnego jako kryterium do przyznania świadczeń rodzinnych
}

\author{
Ernest Nasternak
}

\begin{abstract}
Abstrakt
W opracowaniu podejmowana jest polemika w zakresie ustalania dochodu z wydzierżawionego gospodarstwa rolnego dla celów związanych z przyznaniem prawa do zasiłku rodzinnego. Problem ten ma istotne znaczenie z tego względu, że obecny sposób interpretowania przez sądy przepisów w tym zakresie prowadzi do nierównego traktowania osób ubiegających się o zasiłek rodzinny. W związku z tym $\mathrm{w}$ artykule przedstawiono właściwy, zdaniem autora, sposób interpretacji przedmiotowych przepisów. Pozwoliłby on objąć zakresem pomocy większą liczbę osób, które obecnie są wykluczane z możliwości jej uzyskania. W opracowaniu zwrócono również uwagę na zasadną, zdaniem autora, zmianę stanowiska w jednym z wyroków.
\end{abstract}

Słowa kluczowe: dochód, dzierżawa, zasiłek rodzinny.

Ernest Nasternak, dr nauk prawnych, radca prawny, Ministerstwo Rolnictwa i Rozwoju Wsi, Wydział Samochodów i Maszyn Roboczych - Politechnika Warszawska. 


\section{Wstęp}

Przepisy o świadczeniach rodzinnych stanowią odrębną i wyspecjalizowaną część szeroko rozumianego systemu pomocy społecznej ${ }^{1}$. Jednak, jak zauważają autorzy Komentarza do spraw administracyjnych, społeczno-gospodarcze przeznaczenie świadczeń rodzinnych nie powinno polegać na utrzymywaniu rodzin, lecz raczej na utrzymywaniu dziecka lub dorosłego członka rodziny o niskim dochodzie i wymagającego opieki. Jest to stanowisko utrwalone w doktrynie, gdzie podkreśla się, że społeczno-gospodarcze przeznaczenie świadczeń rodzinnych powinno skupiać się na pomocy konkretnym osobom, a nie rodzinie ${ }^{2}$. Co jeszcze istotne, świadczenia rodzinne, w odróżnieniu od świadczeń z pomocy społecznej, mają charakter roszczeniowy i nie są krótkotrwałymi formami wsparcia umożliwiającego przezwyciężenie trudnych sytuacji. Ich konstrukcja i tym samym założenia oraz stawiane przed nimi cele nie odwołują się do zasady pomocniczości, ani też nie mają na celu aktywizowania ich beneficjentów w celu poprawy ich sytuacji życiowej dzięki własnej zaradności. Z tego wynika, że są rodzajem pomocy udzielanej przez państwo, która ma charakter trwały i jest skierowana na ochronę rodziny, wielodzietności i niepełnosprawności ${ }^{3}$. W związku z tym, jeżeli rodzina uzyskuje dochody nieprzekraczające określonego limitu ${ }^{4}$, to w przypadku złożenia stosownego wniosku i przy spełnieniu dodatkowych przesłanek określonych w przepisach prawa, otrzyma wnioskowane świadczenie. Decyzja w przedmiocie przyznania świadczeń rodzinnych nie jest decyzją uznaniową, lecz decyzją związaną, a zatem ustalenie, że zachodzą okoliczności wskazane w ustawie o świadczeniach rodzinnych przesądza o zasadności przyznania świadczenia. Warto więc zwrócić uwagę, że w przypadku świadczeń rodzinnych brak jest jakiejkolwiek swobody organu co do uznania, że mimo niespełnienia ustawowych przesłanek świadczenie należałoby przyznać ze względu na zaistniałą trudną sytuację finansową, społeczną czy też np. prawną strony. Zatem w przypadku świadczeń rodzinnych, nawet gdyby uprawniony organ stwierdził, że sytuacja finansowa rodziny jest w rzeczywistości gorsza niż to wynika z przyjętych rozwiązań prawnych, nie może zmienić rozstrzygnięcia w przedmiotowym zakresie. Świadczenia rodzinne są bowiem formą pomocy państwa i mogą

1. I. Kamińska, J. Matarewicz, M. Rozbicka-Ostrowska, Komentarz do spraw administracyjnych. Wybrane zagadnienia, WK 2015 r., Lex 256303. Podobnie I. Sierpowska, Ustawa o pomocy społecznej. Komentarz, Kraków, Wolters Kluwer, 2007, s. 22.

2. J. Jończyk, Świadczenia rodzinne [w:] Prawo zabezpieczenia społecznego, Zakamycze 2006, s. 310 i 313.

3. I. Sierpowska, Świadczenia rodzinne [w:] Prawo pomocy społecznej, Oficyna 2008, s. 232.

4. Art. 5 Ustawy z 28 listopada 2003 r. o świadczeniach rodzinnych, Dz. U. 2020 poz. 111 ze zm. 
zostać przyznane dopiero wtedy, gdy rodzice nie mogą sami zaspokoić potrzeb bytowych swoich dziecis. Istnienie prawa do świadczenia rodzinnego nie zwalnia jednak osób zobowiązanych do alimentacji z ciążących na nich obowiązków utrzymywania dziecka i rodziny. W związku z tym należy zwrócić uwagę na cel, jaki ma realizować ustawa o świadczeniach rodzinnych. Mianowicie został on wyrażony w art. 4 ust. 1 ww. ustawy o świadczeniach rodzinnych oraz w przepisach Konstytucji RP z 2 kwietnia 1997 roku$^{6}$, której założenia ustawa o świadczeniach rodzinnych realizuje. Stosownie do art. 4 ust. 1 ustawy o świadczeniach rodzinnych, zasiłek rodzinny ma na celu częściowe pokrycie wydatków na utrzymanie dziecka. Oznacza to, że niewątpliwie zasiłek rodzinny ma być wydatkowany na utrzymanie dziecka, lecz nie można temu świadczeniu przypisać funkcji zapewnienia środków utrzymania rodziny lub nawet dziecka ${ }^{7}$. Niemniej jednak konieczne jest zapewnienie równych i sprawiedliwych zasad dostępu do tych świadczeń, których zadaniem jest pomoc w wychowaniu dzieci. Ze względu na różnice w traktowaniu rodziców często uniemożliwione jest nabycie świadczenia rodzinnego dla dzieci, które w rzeczywistości znajdują się w porównywalnej sytuacji dochodowej z dziećmi, na rzecz których to świadczenie zostało ustalone.

\section{Analiza problemu}

Zgodnie $\mathrm{z}$ art. 3 pkt 1 lit. c ustawy o świadczeniach rodzinnych za dochód rodziny przyjmuje się m.in. dochód uzyskany z gospodarstwa rolnego. $Z$ kolei z treści art. 5 ust. 8 powyższej ustawy wynika, że w przypadku ustalania dochodu z gospodarstwa rolnego przyjmuje się, że z 1 ha przeliczeniowego uzyskuje się dochód miesięczny w wysokości 1/12 dochodu ogłaszanego corocznie w drodze obwieszczenia przez Prezesa Głównego Urzędu Statystycznego. Art. 5 ust. 8a pkt 1 powyższej ustawy stanowi, że ustalając dochód rodziny uzyskany z gospodarstwa rolnego, do powierzchni gospodarstwa stanowiącego podstawę wymiaru podatku rolnego wlicza się obszary rolne oddane $\mathrm{w}$ dzierżawę, $\mathrm{z}$ wyjątkiem oddanej $\mathrm{w}$ dzierżawę, na podstawie umowy dzierżawy zawartej stosownie do przepisów o ubezpieczeniu społecznym rolników, części lub całości znajdującego się w posiadaniu rodziny gospodarstwa rolnego.

5. Patrz: Wyrok WSA w Warszawie z 19 marca 2009 r., I SA/Wa 50/09, LEX nr 533503.

6. Ustawa z 8 września 2006 r. o zmianie Konstytucji Rzeczypospolitej Polskiej, Dz. U. 2006 nr 200 poz. 1471; Ustawa z 7 maja 2009 r. o zmianie Konstytucji Rzeczypospolitej Polskiej, Dz. U. 2009 nr 114 poz. 946.

7. W. Maciejko, Świadczenia rodzinne. Komentarz, Warszawa 2014, s. 94. 
Mając to na względzie należy zaznaczyć, że stosownie do przepisów o świadczeniach rodzinnych ustawodawca przyjął domniemanie, iż z gospodarstwa rolnego uzyskuje się dochód niezależnie od tego, czy prowadzi się w nim osobiście działalność, czy się je wydzierżawia. Zatem przepisy w tym zakresie nie mówią o dochodzie faktycznie osiąganym z działalności rolniczej, lecz zawierają założenie, że kwota wynikająca z przewidzianego w nim wyliczenia jest dochodem miesięcznym przyjętym do ustalenia prawa do zasiłku rodzinnego. Pogląd, zgodnie z którym ustawodawca przyjął domniemanie, że z gospodarstwa rolnego uzyskuje się dochód, Naczelny Sąd Administracyjny wyraził już w wielu orzeczeniach ${ }^{8}$. Wyjątek jednak stanowi sytuacja, gdy gospodarstwo rolne zostało wydzierżawione na podstawie umowy dzierżawy zawartej stosownie do przepisów o ubezpieczeniu społecznym rolników. W Ustawie z 20 grudnia 1990 roku o ubezpieczeniu społecznym rolników ${ }^{9}$ o umowach dzierżawy jest mowa w art. 28 ust. 4 pkt 1, art. 38 pkt 1 oraz art. 117. Jeśli chodzi o ten ostatni wymieniony przepis, to jest to umowa dzierżawy zawierana na podstawie przepisów poprzednio obowiązujących w zakresie ubezpieczenia społecznego rolników, a mianowicie Ustawy z 14 grudnia 1982 roku o ubezpieczeniu społecznym rolników indywidualnych i członków ich rodzin ${ }^{10} . \mathrm{Z}$ tego wynika, że ta ostatnia umowa dzierżawy, ze względu na to, że była zawierana na podstawie obecnie już nieobowiązujących przepisów, ma marginalne znaczenie i wprawdzie jest to umowa zawierana stosownie do przepisów o ubezpieczeniu społecznym rolników, ale jest to inny rodzaj umowy dzierżawy od umów aktualnie zawieranych, o których mowa w art. 28 ust. 4 pkt 1, art. 38 pkt 1 ustawy o ubezpieczeniu społecznym rolników. W tym momencie istotna jest odpowiedź na pytanie, jak traktować dwie pozostałe umowy dzierżawy, o których mowa w art. 28 ust. 4 pkt 1 i art. 38 pkt 1 ustawy o ubezpieczeniu społecznym rolników - czy jest to ta sama umowa, czy może są to dwa odmienne rodzaje umów dzierżawy i zawierane w różnych celach, choć stosownie do przepisów o ubezpieczeniu społecznym rolników.

Analizując orzecznictwo sądowe ${ }^{11}$, należy stwierdzić, że istnieje utrwalone stanowisko w tym zakresie. Zgodnie z tym stanowiskiem, przepisy ww. ustawy o świadczeniach rodzinnych wprowadzają zasadę, że wydzierżawienie gruntów rolnych

8. Wyroki NSA z: 14 grudnia 2007 r., sygn. akt I OSK 321/07; 15 grudnia 2008 r., sygn. akt I OSK 50/08 oraz z 23 czerwca 2009 r., sygn. akt I OSK 1290/08.

9. Obwieszczenie Marszałka Sejmu Rzeczypospolitej Polskiej z 22 stycznia 2021 r. w sprawie ogłoszenia jednolitego tekstu ustawy o ubezpieczeniu społecznym rolników, Dz. U. 2021 poz. 266.

10. Dz. U. 1998 poz. 133 i 190 oraz Dz. U. 1990 poz. 90 i 198.

11. Orzeczenia Naczelnego Sądu Administracyjnego z: 27 października 2006 r., sygn. akt I OSK 601/06; 5 listopada 2008 r., sygn. akt I OSK 1930/07 i I OSK 1929/07; 23 czerwca 2009 r., sygn. akt OSK 1290/08; 3 września 2009 r., sygn. akt I OSK 3/9; 18 lutego 2010 r. sygn. akt I OSK 1425/09; 3 lutego 2011 r. sygn. akt. I OSK 1712/10; 9 marca 2011 r. sygn. akt I OSK 1922/10, 4 lutego 2015 r., sygn. akt I OSK 1906/13. 
stosownie do przepisów o ubezpieczeniu społecznym rolników odnosi się tylko do sytuacji zaprzestania prowadzenia działalności rolniczej przez emeryta lub rencistę w sytuacji, gdy wydzierżawi swoje gospodarstwo rolne osobie niebędącej jego małżonkiem, zstępnym lub pasierbem oraz niepozostającej wraz z nim we wspólnym gospodarstwie domowym. Okres dzierżawy powinien wynosić co najmniej 10 lat, a umowa zawarta w formie pisemnej musi być potwierdzona przez wójta, właściwego ze względu na miejsce położenia przedmiotu dzierżawy (art. 28 ust. 4 pkt 1 ustawy o ubezpieczeniu społecznym rolników). Z tego wynika, że stosownie do przepisów o ubezpieczeniu społecznym rolników umowa dzierżawy może być zawarta przez osobę będącą emerytem lub rencistą, co wiąże się z zaprzestaniem prowadzenia działalności rolniczej i utratą potencjalnego dochodu z gospodarstwa rolnego. Taki jest cel regulacji art. 5 ust. 8a pkt 1 ustawy o świadczeniach rodzinnych w związku z art. 28 ust. 4 ustawy o ubezpieczeniu społecznym rolników ${ }^{12}$. Dlatego w sytuacji, gdy osoba ubiegająca się o przyznanie zasiłku rodzinnego wydzierżawiła gospodarstwo, należy w pierwszej kolejności zbadać, czy umowa dzierżawy spełnia wymogi określone w art. 28 ust. 4 ustawy o ubezpieczeniu społecznym rolników, a $\mathrm{z}$ brzmienia i celu tego przepisu, interpretowanego w związku z art. 5 ust. 8a pkt 1 ustawy o świadczeniach rodzinnych wynika, że jest ona zawierana wyłącznie pomiędzy podmiotami wymienionymi w tych przepisach, w świetle których wydzierżawiającym zawsze pozostaje emeryt lub rencista.

Zatem przyjmując taki tok rozumowania, osoba, która nie jest uprawniona do emerytury rolniczej albo renty rolniczej, nie może zawrzeć umowy dzierżawy gruntów rolnych w trybie przepisów o ubezpieczeniu społecznym rolników. Oznacza to, iż nie została zachowana przesłanka podmiotowa zawarcia umowy dzierżawy. Tym samym zryczałtowany dochód $\mathrm{z}$ wydzierżawionego gospodarstwa rolnego przez osobę niebędącą emerytem albo rencistą podlega doliczeniu do dochodów osiągniętych przez tę osobę z innych źródeł. Trudno jest znaleźć r a ti o le g is takiego rozwiązania, gdzie do dochodu ludzi w większości młodych, którzy potrzebują często pomocy w związku z wychowywaniem dzieci, jest wliczany zryczałtowany dochód $\mathrm{z}$ wydzierżawionego gospodarstwa rolnego, który w rzeczywistości uzyskuje dzierżawca gospodarstwa rolnego. Z kolei dochód dzierżawcy jest pomniejszany o czynsz z tytułu dzierżawy (art. 5 ust. 8b ustawy o świadczeniach rodzinnych). Emeryci rolni, którzy w większości już nie potrzebują pomocy w związku z wychowywaniem dzieci, są zwolnieni z mocy ustawy o świadczeniach rodzinnych z obowiązku doliczania dochodu $\mathrm{z}$ wydzierżawionego gospodarstwa rolnego do dochodu uprawniającego do zasiłku rodzinnego. W związku z tym powstaje wątpliwość, czy

12. Wyrok NSA w Warszawie z 9 marca 2011 r., sygn. akt I OSK 1922/10. 
stworzenie tak mało przejrzystego rozwiązania nie zostało nakierowane na osiągnięcie czysto fiskalnego efektu, jednak kosztem dzieci, które często być może nie uzyskują należnej im pomocy tylko z tego względu, że do dochodu ich rodziny jest doliczany zryczałtowany dochód $\mathrm{z}$ wydzierżawionego gospodarstwa rolnego. Zapewne bardziej przejrzystym rozwiązaniem byłoby doliczanie do dochodu rodziny czynszu z tytułu dzierżawy gospodarstwa rolnego.

Należy jednak zwrócić uwagę, że w art. 38 pkt 1 ustawy o ubezpieczeniu społecznym rolników jest mowa o zaprzestaniu działalności rolniczej, i trzeba podkreślić, że ta regulacja nie odnosi się wyłącznie do emerytów i rencistów rolnych. W ustawie o ubezpieczeniu społecznym rolników ustawodawca jasno określił warunki, jakie należy spełniać, aby podlegać ubezpieczeniu społecznemu rolników. Właściciel gospodarstwa rolnego o powierzchni przekraczającej 1 ha przeliczeniowy, po spełnieniu pozostałych warunków określonych w art. 7 i 16 ustawy o ubezpieczeniu społecznym rolników, podlega temu ubezpieczeniu z mocy prawa, co jednak nie wyklucza wyłączenia takiego rolnika $\mathrm{z}$ obowiązkowego ubezpieczenia w razie obalenia przez zainteresowanego domniemania płynącego z art. 38 pkt 1 tej ustawy. Obowiązkowe ubezpieczenie społeczne rolników oparte jest na domniemaniu faktycznego prowadzenia działalności rolniczej, które może zostać w toku postępowania dowodowego obalone. Ustawodawca tym samym expressis verbis - w kwestii podlegania ubezpieczeniu społecznemu rolników - dał pierwszeństwo stanowi faktycznemu przed stanem własnościowym, czego nie można dostrzec w przepisach regulujących wypłatę świadczeń emerytalno-rentowych, a konkretnie w odniesieniu do art. 28 ust. 4 pkt 1 ww. ustawy o ubezpieczeniu społecznym rolników. Zgodnie z treścią tego przepisu uznaje się, że emeryt lub rencista zaprzestał prowadzenia działalności rolniczej, jeżeli ani on, ani jego małżonek nie są właścicielem (współwłaścicielem) lub posiadaczem gospodarstwa rolnego w rozumieniu przepisów o podatku rolnym i nie prowadzą działu specjalnego, nie uwzględniając gruntów wydzierżawionych, na podstawie umowy pisemnej zawartej co najmniej na 10 lat, której zawarcie potwierdził wójt, właściwy ze względu na miejsce położenia przedmiotu dzierżawy, osobie niebędącej:

a) małżonkiem emeryta lub rencisty,

b) jego zstępnym lub pasierbem,

c) osobą pozostającą z emerytem lub rencistą we wspólnym gospodarstwie domowym,

d) małżonkiem osoby, o której mowa w lit. b lub c.

W związku z powyższym, rolą art. 28 ust. 4 pkt 1 ww. ustawy jest budowa normy prawnej dotyczącej zawieszenia wypłaty części uzupełniającej świadczeń emerytalno-rentowych rolniczych w przypadku posiadania gospodarstwa rolnego 
po uzyskaniu prawa do tych świadczeń, przez co rozumie się, zgodnie z tym przepisem, prowadzenie działalności rolniczej. Warto zwrócić uwagę, że w przypadku ubiegania się o prawo do tzw. wcześniejszej emerytury rolniczej zaprzestanie działalności rolniczej w myśl art. 6 pkt 3 ww. ustawy ${ }^{13}$ stanowiło przesłankę warunkującą ustalenie prawa do tego świadczenia, a to oznaczało, że wymagane było wyzbycie się posiadania gospodarstwa rolnego. Na dodatek rolnik ubiegający się o wcześniejszą emeryturę nie był emerytem, gdyż decyzja o przyznaniu tego świadczenia miała charakter konstytutywny, a nie jak decyzja o ustaleniu prawa do emerytury po osiągnięciu wieku emerytalnego, której należy przyznać charakter deklaratywny. W związku z tym osoba, która zaprzestawała działalności rolniczej w związku z ubieganiem się o wcześniejszą emeryturę i w tym celu wydzierżawiała gospodarstwo rolne $z$ jednoczesnym wpisem tej umowy do ewidencji gruntów i budynków, nie spełniała warunków, o których mowa w art. art. 28 ust. 4 pkt 1 ww. ustawy o ubezpieczeniu społecznym rolników. W tym przypadku jako podstawę do zawarcia umowy dzierżawy należało wskazać art. 38 pkt 1 tej ustawy. Mając to wszystko na względzie można na dodatek stwierdzić, literalnie interpretując art. 28 ust. 4 pkt 1 ww. ustawy o ubezpieczeniu społecznym rolników, że ustawodawca milczy na temat faktycznego prowadzenia działalności rolniczej w kwestii świadczeń emerytalno-rentowych i pozostawia na marginesie sprawę prowadzenia lub nieprowadzenia działalności rolniczej jako pozostającą bez znaczenia dla wypłaty części uzupełniającej świadczenia. W związku z tym głównym celem tego przepisu jest wymiana pokoleniowa wśród kierowników gospodarstw rolnych, a nie sam fakt zaprzestawania prowadzenia działalności rolniczej przez osoby uprawnione do świadczeń emerytalno-rentowych. W konsekwencji możliwe byłoby postawienie tezy, że regulacja zawarta w art. 38 pkt 1 ustawy o ubezpieczeniu społecznym rolników odnosi się do podlegania ubezpieczeniu społecznemu rolników, co ustawodawca określił przez użycie w tym przepisie zwrotu „przy ustalaniu podlegania ubezpieczeniu domniemywa się...”. Wskazując na różnice między tymi przepisami, można stwierdzić, że zgodnie $\mathrm{z}$ art. 38 pkt 1 ustawy o ubezpieczeniu społecznym rolników nie ma znaczenia, kto jest wydzierżawiającym, tzn. może nim być zarówno aktywny rolnik, jak i emeryt lub rencista. Tym samym należy dostrzec różnice pomiędzy umową dzierżawy, o której mowa w art. 38 ust. 1 ww. ustawy, a umową dzierżawy określoną w art. 28 ust. 4 pkt 1 ww. ustawy, dla której zostały określone szczególne rozwiązania warunkujące możliwość wypłaty części uzupełniającej świadczeń emerytalno-rentowych rolniczych

13. Przez działalność rolniczą w rozumieniu art. 6 pkt 3 ww. ustawy o ubezpieczeniu społecznym rolników rozumie się działalność w zakresie produkcji roślinnej lub zwierzęcej, w tym ogrodniczej, sadowniczej, pszczelarskiej i rybnej. 
i której celem jest to, aby ziemia emerytów lub rencistów przechodziła w ręce nowych rolników zdolnych do prowadzenia efektywnie działalności rolniczej, a nie sam fakt zaprzestania prowadzenia tejże działalności.

Uzasadnienie tezy o różnym charakterze i potrzebie rozróżniania umów dzierżawy znajduje dodatkowe potwierdzenie w $\$ 11$ ust. 1 pkt 2 Rozporządzenia Ministra Rozwoju Regionalnego i Budownictwa z 29 marca 2001 roku w sprawie ewidencji gruntów i budynków ${ }^{14}$, zgodnie z którym w ewidencji gruntów i budynków wykazuje się m.in. dane o gruntach, które są przedmiotem umów dzierżawy, oraz o dzierżawcach tych gruntów, zgłaszanych do ewidencji w związku z przepisami art. 28 ust. 4 pkt 1, art. 38 pkt 1 oraz art. 117 Ustawy z 20 grudnia 1990 roku o ubezpieczeniu społecznym rolników. Przedmiotowe brzmienie tego przepisu zostało nadane Rozporządzeniem Ministra Administracji i Cyfryzacji z 29 listopada 2013 roku zmieniającym rozporządzenie w sprawie ewidencji gruntów i budynków ${ }^{15}$. Do czasu tej zmiany brzmienie $\$ 11$ ust. 1 pkt 2 rozporządzenia w sprawie ewidencji gruntów i budynków ograniczone było w ten sposób, że w ewidencji wykazywane były dane dotyczące osób i jednostek organizacyjnych, które władają gruntami na podstawie umów dzierżawy, zwanych dalej „dzierżawcami”, zgłoszonych do ewidencji stosownie do art. 28 ust. 4 pkt 3 Ustawy z 20 grudnia 1990 roku o ubezpieczeniu społecznym rolników. W uzasadnieniu do ww. projektu zmieniającego rozporządzenie w sprawie ewidencji gruntów i budynków zaznaczono, że „Proponowana zmiana $\$ 11$ ust. 1 pkt 2 ( $\$ 1$ pkt 7 lit. a projektu rozporządzenia) wynika $z$ tego, że przepis ten w dotychczasowym brzmieniu nie uwzględniał wszystkich przepisów prawa, które uzależniają nabycie odpowiednich praw przez właściciela wydzierżawionych gruntów od ujawnienia umowy dzierżawy dotyczącej tych gruntów w ewidencji”.

$\mathrm{Z}$ tego wynika, że w rozporządzeniu ${ }^{16} \mathrm{w}$ sprawie ewidencji gruntów i budynków rozróżniono trzy niezależne podstawy do zawarcia umowy dzierżawy, które są zawierane stosownie do przepisów o ubezpieczeniu społecznym rolników i wykazywane w ewidencji gruntów i budynków. W konsekwencji przyjmując, że w myśl art. 38

14. Obwieszczenie Ministra Inwestycji i Rozwoju z 3 stycznia 2019 r. w sprawie ogłoszenia jednolitego tekstu rozporządzenia Ministra Rozwoju Regionalnego i Budownictwa w sprawie ewidencji gruntów i budynków, Dz. U. 2019 poz. 393.

15. Rozporządzenie Ministra Administracji i Cyfryzacji z 29 listopada 2013 r. zmieniające rozporządzenie w sprawie ewidencji gruntów i budynków, Dz. U. 2013 poz. 1551.

16. Na marginesie należy zaznaczyć, że omawiane rozporządzenie obowiązuje do 31 lipca $2021 \mathrm{r}$. Ma to związek z tym, że od 31 lipca 2020 r. weszła w życie Ustawa z 16 kwietnia 2020 r. o zmianie ustaw - Prawo geodezyjne i kartograficzne oraz niektórych innych ustaw (Dz. U. 2020 poz. 782). Przedmiotową ustawą wprowadzone zostały zmiany w przepisach o ubezpieczeniu społecznym rolników. Do czasu wprowadzenia omawianej zmiany, zgodnie z przepisami o ubezpieczeniu społecznym rolników, umowy, o których mowa w art. 28 ust. 4 pkt 1 i art. 38 pkt 1 były rejestrowane w ewidencji gruntów i budynków, a po zmianie są potwierdzone przez wójta, właściwego ze względu na miejsce położenia przedmiotu dzierżawy. 
ust. 1 ww. ustawy o ubezpieczeniu społecznym rolników wydzierżawiającym może być osoba chcąca wykazać, że zaprzestała prowadzenia działalności rolniczej i tym samym zostać wyłączoną z obowiązku podlegania ubezpieczeniu społecznemu rolników, powinna mieć prawo do niewliczania zryczałtowanego dochodu z gospodarstwa rolnego do dochodu warunkującego nabycie zasiłku rodzinnego, mimo że nie jest emerytem lub rencistą rolnym. Umowa dzierżawy zawierana stosownie do art. 38 ust. 1 ww. ustawy, zgodnie $\mathrm{z}$ omawianym przepisem rozporządzenia $\mathrm{w}$ sprawie ewidencji gruntów i budynków, jest rejestrowana w ewidencji gruntów i budynków bez żadnych dodatkowych wymogów co do podmiotów, między którymi dochodzi do jej zawarcia. Tym samym brakuje uzasadnienia, dlaczego taka wykładnia nie powinna towarzyszyć stosowaniu przepisów o świadczeniach rodzinnych, a konkretnie art. 5 ust 8 a pkt 1 tej ustawy.

W tym miejscu warto zwrócić uwagę, że analogiczna kwestia występuje na podstawie przepisów Ustawy z 11 lutego 2016 roku o pomocy państwa w wychowaniu dzieci $^{17}$. W tej ustawie również mieliśmy do czynienia $\mathrm{z}$ utrwaloną $\mathrm{w}$ orzecznictwie wykładnią $^{18}$, ukształtowaną na tle identycznie sformułowanego przepisu art. 7 ust. 6 jak w art. 5 ust. 8a Ustawy z 28 listopada 2003 roku o świadczeniach rodzinnych ${ }^{19}$, gdzie umowa dzierżawy, stosownie do przepisów o ubezpieczeniu społecznym rolników, jest zawierana wyłącznie pomiędzy podmiotami, w świetle których wydzierżawiającym zawsze pozostaje emeryt lub rencista. W powyższym kontekście na uwagę zasługuje wyrok Wojewódzkiego Sądu Administracyjnego w Poznaniu ${ }^{20}$, w którym sąd nie podzielił stanowiska co do tego, że tylko umowa dzierżawy gospodarstwa rolnego, w której wydzierżawiającym jest emeryt lub rencista, zwalnia $z$ obowiązku uwzględniania dochodu (wyliczonego ryczałtowo) przy ustalaniu dochodu rodziny w postępowaniu o przyznanie świadczenia wychowawczego. Analizowany przez sąd przepis art. 7 ust. 6 pkt 1 ustawy o pomocy państwa w wychowaniu dzieci w brzmieniu „oddanej w dzierżawę na podstawie umowy dzierżawy zawartej stosownie do przepisów o ubezpieczeniu społecznym rolników", zdaniem tego sądu nie wskazuje, że odesłanie odnosi się do strony podmiotowej umowy wskazanej w przepisach o ubezpieczeniu społecznym rolników. Wyraźnie bowiem odsyła do definicji umowy, a nie osoby, która może taką umowę zawrzeć. Jak zastrzegł sąd, stroną takiej umowy z pewnością jest członek rodziny, której dochód ustala się dla potrzeb świadczenia wychowawczego. W dalszej

17. Ustawa z 24 czerwca 2021 r. o zmianie niektórych ustaw związanych ze świadczeniami na rzecz rodziny, Dz. U. 2021 poz. 1162.

18. Wyrok Wojewódzkiego Sądu Administracyjnego w Lublinie z 27 września 2018 r., II SA/Lu 683/17.

19. Dz. U. 2020 poz. 111 ze zm.

20. Wyrok Wojewódzkiego Sądu Administracyjnego w Poznaniu z 18 lipca 2019 r., II SA/Po 186/19. 
części tego przepisu jest bowiem mowa o oddanej w dzierżawę części lub całości znajdującego się w posiadaniu rodziny gospodarstwa rolnego. Nie znajduje zatem żadnego uzasadnienia uznanie, że wydzierżawiającym może być tylko emeryt lub rencista. Ustawa o ubezpieczeniu społecznym rolników nie zawiera odrębnej definicji takiej umowy. Jej niezbędne elementy są jednak w tej ustawie przewidziane. To, że w art. 28 ust. 4 pkt 1 ustawy o ubezpieczeniu społecznym rolników wskazano na osobę emeryta i rencisty jako wydzierżawiającego nie oznacza, że w świetle art. 7 ust. 6 pkt 1 ustawy o pomocy państwa w wychowaniu dzieci ma nim być tylko emeryt i rencista. Skoro art. 28 ust. 4 ustawy o ubezpieczeniu społecznym rolników reguluje sytuacje, w których uznaje się, że emeryt lub rencista zaprzestał prowadzenia działalności rolniczej, oczywiste jest, że wskazuje się na emeryta lub rencistę. Nie oznacza to jednak, że w świetle cyt. art. 7 ust. 6 pkt 1 ustawy o pomocy państwa w wychowaniu dzieci tylko emeryt lub rencista zawierający umowę dzierżawy w formie pisemnej na 10 lat z osobą obcą może być zwolniony $\mathrm{z}$ wliczania dochodu $\mathrm{z}$ oddanego $\mathrm{w}$ taki sposób w dzierżawę gospodarstwa rolnego. Zauważyć należy, że art. 7 ust. 6 pkt 1 ustawy o pomocy państwa w wychowaniu dzieci odsyła do przepisów o ubezpieczeniu społecznym rolników, a nie tylko do art. 28 ust. 4 ustawy o ubezpieczeniu społecznym rolników. Ustawa ta nie reguluje jedynie sytuacji emerytów i rencistów, nie ma również żadnego uzasadnienia, już choćby z uwagi na adresatów świadczeń wychowawczych, by w zakresie rozważanym odnosić się jedynie do emerytów i rencistów. Odnosząc się do kwestii domniemania prowadzenia działalności rolniczej i zaprzestania jej prowadzenia, ustawa o ubezpieczeniu społecznym rolników nie ogranicza się jedynie do emerytów i rencistów. W art. 32 ustawy odpowiednio nakazuje stosować art. 28 ust. 4 do osoby pełnoletniej (przepis dotyczy wypłacania renty rodzinnej). Już z tego względu ograniczanie wykładni przepisu art. 7 ust. 6 pkt 1 ustawy o pomocy państwa w wychowaniu dzieci tylko do treści art. 28 ust. 4 ustawy o ubezpieczeniu społecznym rolników nie jest uzasadnione. Warto również wskazać na treść art. 38 ustawy o ubezpieczeniu społecznym rolników, zgodnie z którym domniemanie prowadzenia działalności rolniczej na gruntach rolnych obejmuje właściciela gruntów lub dzierżawcę takich gruntów, jeżeli dzierżawa jest zarejestrowana w ewidencji gruntów i budynków. W ustawie o ubezpieczeniu społecznym rolników w art. 117 wskazano, że rejestracji w ewidencji gruntów i budynków podlegają umowy dzierżawy zawarte stosownie do art. 2 pkt 6 lit b ustawy powołanej w art. 122, czyli uchylonej Ustawy z 14 grudnia 1982 roku o ubezpieczeniu społecznym rolników indywidualnych i członków ich rodzin (Dz. U. 1989 nr 24 poz.133). Zgodnie z art. 2 pkt 6 lit b ustawy z 14 grudnia 1982 roku wskazano, że jest to dzierżawa gruntów wchodzących w skład gospodarstwa rolnego osobie 
niebędącej małżonkiem, zstępnym, małżonkiem zstępnego rolnika i niepozostającej z rolnikiem we wspólnym gospodarstwie domowym na podstawie umowy dzierżawy zwartej co najmniej na okres 10 lat. Przy spełnieniu tych warunków to dzierżawca, a nie właściciel gruntów podlegać będzie ubezpieczeniu społecznemu rolników jako prowadzący gospodarstwo rolne i dochód z gospodarstwa przez niego osiągany nie jest dochodem wydzierżawiającego. Zdaniem tego sądu, skoro w art. 7 ust. 6 pkt 1 ustawy o pomocy państwa w wychowaniu dzieci odesłano do umowy zawartej stosownie do przepisów o ubezpieczeniu społecznym rolników, to z tych przepisów wynika, że winna być to umowa pisemna, zawarta na co najmniej 10 lat z osobą obcą i zgłoszona do ewidencji gruntów i budynków. Wówczas bowiem, a nie tylko w sytuacji, gdy wydzierżawiający jest emerytem lub rencistą, można uznać, że zaprzestał on prowadzenia działalności rolniczej. Zdaniem sądu, skoro skarżąca wykazała, że zawarta przez nią umowa warunki te spełnia i stanowi wskazaną w art. 7 ust. 1 pkt 6 ustawy o pomocy państwa w wychowaniu dzieci umowę zawartą stosownie do przepisów o ubezpieczeniu społecznym rolników, nie dochód $\mathrm{z}$ wydzierżawionego gospodarstwa rolnego, tylko uzyskiwany czynsz dzierżawny winien być wliczany do dochodu przy ustalaniu kryterium dochodowego.

Sąd stwierdził zatem w omawianym wyroku, że właściwe organy, doliczając dochód z gospodarstwa rolnego, naruszyły art. 7 ust. 6 pkt 1 ustawy o pomocy państwa w wychowaniu dzieci i tym samym decyzje podlegały uchyleniu. Ustalając kryterium dochodowe, $\mathrm{z}$ uwzględnieniem wykładni art. 7 ust. 6 pkt 1 o pomocy państwa w wychowaniu dzieci przedstawionej w niniejszym wyroku, należy to czynić z uwzględnieniem czynszu dzierżawnego, a nie ryczałtowego dochodu z gospodarstwa rolnego. Jest to stanowisko zgodne z prezentowanym już podejściem, które jeszcze nie zyskało powszechnej aprobaty ${ }^{21}$, ale należy je wskazywać jako właściwe, aby osoby, które powinny liczyć na uzyskanie należnych świadczeń w związku z wychowywaniem dziecka, mogły je uzyskać zgodnie z obowiązującymi przepisami prawa, które nadal w większości nie są właściwie interpretowane. Wprawdzie sąd użył w omawianym wyroku dodatkowych argumentów, poza tymi w prezentowanym w artykule stanowisku, ale należy uznawać, że nie są one sprzeczne, a jedynie stanowią dodatkowe przesłanki przemawiające za trafnością omówionego w artykule poglądu.

21. E. Nasternak, Ustalanie dochodu dla celów związanych ze świadczeniami rodzinnymi w stosunku do osób, które wydzierżawily gospodarstwa rolne, „Ubezpieczenia w Rolnictwie. Materiały i Studia” 2017, nr 62. 


\section{Podsumowanie}

W związku z powyższym uzasadniona jest zmiana wykładni przedmiotowych przepisów o świadczeniach rodzinnych, co pozwoli uniknąć tego, że osobie niebędącej emerytem albo rencistą, a będącej właścicielem gospodarstwa rolnego, które zostało wydzierżawione stosownie do art. 38 ust. 1 ustawy o ubezpieczeniu społecznym rolników, dolicza się zryczałtowany dochód z wydzierżawionego gospodarstwa rolnego podczas ubiegania się o świadczenia rodzinne. Wynika to $\mathrm{z}$ tego, że mając chociażby na względzie ww. rozporządzenie w sprawie ewidencji gruntów i budynków, zawarcie umowy dzierżawy gruntów rolnych - stosownie do przepisów o ubezpieczeniu społecznym rolników - nie dotyczy wyłącznie emerytów i rencistów. Co za tym idzie, zryczałtowany dochód z wydzierżawionego gospodarstwa rolnego przez osobę niebędącą emerytem albo rencistą nie powinien być doliczany do dochodów osiągniętych przez tę osobę z innych źródeł, które warunkują nabycie np. zasiłku rodzinnego, będącego jednym ze świadczeń przyznawanych na podstawie przepisów ww. ustawy o świadczeniach rodzinnych. Ewentualnie, jak wskazano powyżej, do dochodu powinien być doliczany czynsz dzierżawny w wysokości wynikającej z umowy dzierżawy, co pozwoliłoby przyznawać świadczenia rodzinne na podstawie właściwie ustalonej sytuacji osobistej, rodzinnej, dochodowej i majątkowej osób czy rodzin.

\section{Bibliografia}

Jończyk J., Świadczenia rodzinne [w:] Prawo zabezpieczenia społecznego, Zakamycze 2006.

Kamińska I., Matarewicz J., Rozbicka-Ostrowska M., Komentarz do spraw administracyjnych. Wybrane Zagadnienia, WK 2015 r., Lex 256303.

Konstytucja RP z 2 kwietnia 1997 r., Dz. U. 2006 nr 200 poz. 1471 oraz nr 114 poz. 946.

Maciejko W., Świadczenia rodzinne. Komentarz, C.H. Beck 2014.

Nasternak E., Ustalanie dochodu dla celów związanych ze świadczeniami rodzinnymi w stosunku do osób, które wydzierżawiły gospodarstwa rolne, „Ubezpieczenia w Rolnictwie. Materiały i Studia” 2017, nr 62.

Orzeczenie Naczelnego Sądu Administracyjnego z 27 października 2006 r., sygn. akt I OSK 601/06.

Orzeczenie Naczelnego Sądu Administracyjnego z 5 listopada 2008 r., sygn. akt I OSK 1930/07 i I OSK 1929/07.

Orzeczenie Naczelnego Sądu Administracyjnego z 23 czerwca 2009 r., sygn. akt OSK 1290/08.

Orzeczenie Naczelnego Sądu Administracyjnego z 3 września 2009 r., sygn. akt I OSK 3/9.

Orzeczenie Naczelnego Sądu Administracyjnego z 18 lutego 2010 r., sygn. akt I OSK 1425/09. 
Opinia krytyczna do przeważającego poglądu reprezentowanego w orzecznictwie sądowym

Orzeczenie Naczelnego Sądu Administracyjnego z 3 lutego 2011 r., sygn. akt. I OSK 1712/10.

Orzeczenie Naczelnego Sądu Administracyjnego z 9 marca 2011 r., sygn. akt I OSK 1922/10.

Orzeczenie Naczelnego Sądu Administracyjnego z 4 lutego 2015 r., sygn. akt I OSK 1906/13.

Rozporządzenie Ministra Rozwoju Regionalnego i Budownictwa z 29 marca 2001 r. w sprawie ewidencji gruntów i budynków, Dz. U. 2019 poz. 393.

Rozporządzenie Ministra Administracji i Cyfryzacji z 29 listopada 2013 r. zmieniające rozporządzenie w sprawie ewidencji gruntów i budynków, Dz. U. 2013 poz. 1551.

Sierpowska I., Świadczenia rodzinne [w:] Prawo pomocy społecznej, Oficyna 2008.

Sierpowska I., Ustawa o pomocy społecznej. Komentarz, Kraków, Wolters Kluwer 2007.

Ustawa z 14 grudnia 1982 r. o ubezpieczeniu społecznym rolników indywidualnych i członków ich rodzin, Dz. U. 1998 poz. 133 i 190 oraz Dz. U. 1990 poz. 90 i 198.

Ustawa z 20 grudnia 1990 r. o ubezpieczeniu społecznym rolników, Dz. U. 2021 poz. 266.

Ustawa z 28 listopada 2003 r. o świadczeniach rodzinnych, Dz. U. 2020 poz. 111 ze zm.

Ustawa z 11 lutego 2016 r. o pomocy państwa w wychowaniu dzieci, Dz. U. 2021 poz. 1162.

Wyrok NSA z 14 grudnia 2007 r., sygn. akt I OSK 321/07.

Wyrok NSA z 15 grudnia 2008 r., sygn. akt I OSK 50/08.

Wyrok Wojewódzkiego Sądu Administracyjnego w Lublinie z 27 września 2018 r., II SA/Lu 683/17.

Wyrok Wojewódzkiego Sądu Administracyjnego w Poznaniu z 18 lipca 2019 r., II SA/Po 186/19.

Wyrok Wojewódzkiego Sądu Administracyjnego w Warszawie z 19 marca 2009 r., I SA/Wa 50/09, LEX nr 533503. 


\title{
Opinion critical of the prevailing view the jurisprudence of the courts as regards the determination of the income from a rented agricultural holding as a criterion for granting family benefits
}

\author{
Ernest Nasternak
}

\begin{abstract}
The study engages in polemics in the field of determining income from a leased farm for the purposes related to granting the right to family allowance. This problem is of significant importance due to the fact that the current way of interpreting the provisions in this respect by the courts leads to unequal treatment of persons applying for child benefit. Therefore, the article presents the proper, in the author's opinion, way to interpret the provisions in question. It would allow more people who are currently excluded to be covered. The paper also draws attention to a legitimate, in the author's opinion, change of position in one of the judgments.
\end{abstract}

Keywords: income, tenancy, family allowance.

Ernest Nasternak, Doctor of Law, Legal Counsel, Ministry of Agriculture and Rural Development, Faculty of Automobiles and Working Machines - Warsaw University of Technology. 


\section{Introduction}

The provisions on family benefits are a separate and specialised part of the broadly defined social welfare system ${ }^{1}$. However, as the authors of the Administrative Commentary note, the socio-economic purpose of family benefits should not be to support families, but rather to support a low-income, vulnerable child or adult family member. This is a well-established position in doctrine, where it is stressed that the socioeconomic purpose of family benefits should focus on helping specific individuals, not families ${ }^{2}$. What else is important, family benefits, unlike social assistance benefits, have a claim nature and are not short-term forms of support enabling overcoming difficult situations. Their construction and thus their assumptions and objectives do not refer to the principle of subsidiarity, nor do they aim to activate their beneficiaries in order to improve their life situation thanks to their own resourcefulness. It follows that they are a type of aid granted by the State which is of a permanent nature and is intended to protect the family, multiple children and disability ${ }^{3}$. Therefore, if a family receives income below a certain limit ${ }^{4}$, then, in case of filing an appropriate application and meeting additional conditions specified in the provisions of the law, he will receive the requested benefit. A decision to grant family benefits is not a discretionary decision, but a binding decision, and a finding that the circumstances set out in the Family Benefits Act are present determines whether it is justified to grant the benefit. It is therefore worth noting that in the case of family benefits there is no freedom of the authority to decide that despite not meeting the statutory requirements the benefit should be granted due to a difficult financial, social or e.g. legal situation of the party. Therefore, in the case of family benefits, even if the authorised body found that the financial situation of a family is in fact worse than it results from the adopted legal solutions, it cannot change the ruling in this respect. Family benefits are a form of state aid and can only be granted when the parents do not ${ }^{5}$. The existence of entitlement to family benefit does not, however, release persons having maintenance obligations from their duty to maintain the child and the family. In this connection, attention should be drawn to the purpose of the Family Benefits Act. Namely, it has been expressed in Article 4 Section 1 of the aforementioned Act on family benefits and in the provisions

1. I. Kamińska, J. Matarewicz, M. Rozbicka-Ostrowska, Komentarz do spraw administracyjnych. Wybrane zagadnienia, WK 2015 r., Lex 256303. Podobnie I. Sierpowska, Ustawa o pomocy społecznej. Komentarz, Kraków, Wolters Kluwer, 2007, p. 22.

2. J. Jończyk, Świadczenia rodzinne [in:] Prawo zabezpieczenia społecznego, Zakamycze 2006, p. 310 and 313.

3. I. Sierpowska, Świadczenia rodzinne [in:] Prawo pomocy społecznej, Oficyna 2008, p. 232.

4. Art. 5 Ustawy z 28 listopada 2003 r. o świadczeniach rodzinnych, Dz. U. 2020 poz. 111 ze zm.

5. See: Wyrok WSA w Warszawie z 19 marca 2009 r., I SA/Wa 50/09, LEX nr 533503. 
of the Constitution of the Republic of Poland of 2 April 19976, the assumptions of which are implemented by the Act on family benefits. Pursuant to Article 4 par. 1 of the Act on Family Benefits, family allowance is aimed at partial coverage of expenses for the maintenance of a child. This means that child benefit is undoubtedly intended to be spent on the maintenance of the child, but that the function of providing for the maintenance of the family or even of the child cannot be attributed to that benefit ${ }^{7}$. However, it is necessary to ensure equal and fair access to these benefits, which are designed to help raise children. Due to differences in parental treatment, the acquisition of child benefit is often prevented for children who are in fact in a comparable income situation to the children for whom the benefit has been established.

\section{Analysis of the problem}

Pursuant to Art. 3 point 1 letter c of the Act on family benefits, family income is considered to include income from an agricultural holding. It follows from the provisions of Art. 5 section 8 of the above mentioned Act, in turn, that in case of determining the income from an agricultural holding, it is assumed that 1 ha of calculation area yields a monthly income of $1 / 12$ of the income announced annually by the President of the Central Statistical Office by way of a notice. Art. $5 \mathrm{sec}$. $8 \mathrm{a}$ item 1 of the aforementioned Act states that when establishing the family income from an agricultural holding, the area of the holding which constitutes the basis for assessment of the agricultural tax shall include the agricultural areas leased out, with the exception of a part or the entire agricultural holding held by the family under a lease agreement concluded pursuant to the provisions of the social insurance for farmers.

With this in mind, it should be noted that in accordance with the provisions on family benefits, the legislator has adopted a presumption that an agricultural holding generates income regardless of whether it is operated or leased out personally. Thus, the legislation in question does not refer to the income actually earned from agricultural activity, but contains an assumption that the amount resulting from the calculation provided for therein is the monthly income used to establish entitlement to family allowances. The view, according to which the legislator adopted a presumption that income is obtained from an agricultural holding, was already expressed by the Supreme

6. Ustawa z 8 września 2006 r. o zmianie Konstytucji Rzeczypospolitej Polskiej, Dz. U. 2006 nr 200 poz. 1471; Ustawa z 7 maja 2009 r. o zmianie Konstytucji Rzeczypospolitej Polskiej, Dz. U. 2009 nr 114 poz. 946.

7. W. Maciejko, Świadczenia rodzinne. Komentarz, Warszawa 2014, p. 94. 
Administrative Court in many judgments ${ }^{8}$. An exception, however, is the situation where an agricultural holding has been leased under a tenancy agreement concluded in accordance with the provisions of social insurance for farmers. In the Act of 20 December 1990 on social insurance of farmers ${ }^{9}$ lease agreements are referred to in Articles 28(4)(1), 38(1) and 117. As regards the latter, it is a lease agreement concluded on the basis of provisions previously in force with respect to social insurance for farmers, namely the Act of 14 December 1982 on social insurance for individual farmers and members of their families ${ }^{10}$. It follows that the latter lease agreement, due to the fact that it was entered into on the basis of provisions no longer in force, is of marginal significance and, although it is an agreement entered into pursuant to the provisions on social insurance for farmers, it is a different type of lease agreement from the current ones referred to in Article 28(4)(1), article 38(1) of the Act on Social Insurance of Farmers. At this point it is important to answer the question of how to treat the two other lease agreements referred to in Articles 28(4)(1) and 38(1) of the Act on social insurance for farmers - whether they are the same agreement, or whether they are two different types of lease agreements and concluded for different purposes, albeit in accordance with the provisions on social insurance for farmers.

Analysing the jurisprudence of the courts ${ }^{11}$, it should be stated that there is a well-established position in this regard. According to this position, the provisions of the above mentioned Law on family benefits introduce the rule that the lease of agricultural land in accordance with the provisions of the social insurance of farmers relates only to a situation where a pensioner ceases to carry out agricultural activity when he leases his agricultural holding to a person who is not his spouse, descendant or stepchild and who does not remain in a common household with him. The term of the lease should be at least 10 years and the agreement concluded in writing must be certified by the head of the village which has jurisdiction over the location of the leased property (Article 28(4)(1) of the Act on Social Security for Farmers). It follows that in accordance with the provisions of the social insurance of farmers, a lease agreement may be concluded by a person who is a pensioner, which involves the cessation of agricultural activity and the loss of potential income from

8. Judgments of the Supreme Administrative Court of: 14 December 2007, ref. files I OSK 321/07; 15 December 2008, ref. i OSK 50/08 and of 23 June 2009, sygn. files I OSK 1290/08.

9. Obwieszczenie Marszałka Sejmu Rzeczypospolitej Polskiej z 22 stycznia 2021 r. w sprawie ogłoszenia jednolitego tekstu ustawy o ubezpieczeniu społecznym rolników, Dz. U. 2021 poz. 266.

10. Dz. U. 1998 poz. 133 i 190 oraz Dz. U. 1990 poz. 90 i 198.

11. Judgments of the Supreme Administrative Court of: 27 October 2006, sygn. files I OSK 601/06; 5 November 2008, ref. files I OSK 1930/07 and I OSK 1929/07; 23 June 2009, ref. oSK 1290/08; 3 September 2009, ref. files I OSK 3/9; 18 February 2010 ref. files I OSK 1425/09; 3 February 2011 ref. act. I OSK 1712/10; 9 March 2011 ref. files I OSK 1922/10, 4 February 2015, sygn. files I OSK 1906/13. 
the farm. This is the purpose of regulation of Article 5(8a)(1) of the Family Benefits Act in conjunction with Article 28(4) of the Act on Social Insurance of Farmers ${ }^{12}$. Therefore, in a situation where a person applying for family allowance leased a farm, it should first be examined whether the lease agreement meets the requirements set out in Article 28(4) of the Act on Social Security for Farmers, and it follows from the wording and purpose of that provision, read in conjunction with Article 5(8a)(1) of the Act on Family Benefits, that it is concluded only between the entities mentioned in those provisions, according to which the lessor is always the pensioner. Therefore, taking this line of reasoning, a person who is not entitled to an agricultural pension or an agricultural allowance cannot conclude a contract for the lease of agricultural land under the provisions of the social insurance of farmers. This means that the subjective condition of concluding a lease agreement was not fulfilled. Thus, the lump-sum income from an agricultural holding leased out by a person who is not a pensioner shall be added to the income earned by that person from other sources. It is difficult to find the ratio legis of such a solution, where the income of mostly young people, who often need help in connection with bringing up their children, includes the flat-rate income from a leased farm, which is actually received by the tenant of the farm. In turn, the tenant's income is reduced by the rent from the lease (Article 5(8b) of the Family Benefits Act). Retired farmers, most of whom are no longer in need of child-raising support, are exempted under the Family Benefits Act from the obligation to add income from their leased farm to their income for family allowances. This raises doubts as to whether the creation of such a non-transparent solution was not aimed at achieving a purely fiscal effect, but at the expense of children, who often may not receive the assistance due to them simply because the flatrate income from the leased farm is added to their family income. Probably a more transparent solution would be to add the rent from the farm to the family income.

It should be noted, however, that Article 38(1) of the Act on Social Insurance of Farmers refers to the cessation of agricultural activity, and it should be stressed that this regulation does not refer only to pensioners of agricultural origin. In the Act on social insurance of farmers the legislator has clearly defined the conditions to be met in order to be subject to social insurance of farmers. The owner of an agricultural holding with an area exceeding 1 conversion ha, after meeting the other conditions laid down in Articles 7 and 16 of the Act on Social Insurance of Farmers, is subject to that insurance by virtue of law, which, however, does not exclude such a farmer from compulsory insurance if the interested party rebuts the presumption arising from Article 38(1) of that Act. Compulsory social insurance for farmers is based on a presumption

12. Wyrok NSA w Warszawie z 9 marca 2011 r., sygn. akt I OSK 1922/10. 
of actual agricultural activity, which may be rebutted in the course of evidence proceedings. In this way the legislator explicitly verbis - in the issue of being subject to social insurance of farmers - gave priority to the factual state before the ownership state, which cannot be noticed in the provisions regulating the payment of pension benefits, namely in relation to Article 28 Section 4 point 1 of the above mentioned Act on social insurance of farmers. Pursuant to that provision, a pensioner is deemed to have ceased agricultural activity if neither he nor his spouse is the owner (co-owner) or holder of an agricultural holding within the meaning of the provisions on agricultural tax and does not carry out a special section, not including land leased under a written agreement concluded for at least 10 years and certified by the head of the district, the competent authority for the place where the object of the trade is located:

(a) the spouse of a pensioner,

(b) his descendant or stepchild,

(c) a person living in the same household as the pensioner,

(d) the spouse of the person referred to in point (b) or (c).

In connection with the above, the role of art. 28 section 4 point 1 of the above mentioned act is construction of the legal norm concerning suspension of payment of the supplementary part of the agricultural pension benefits in case of possession of an agricultural holding after obtaining the right to these benefits, which, according to this provision, is understood as conducting agricultural activity. It is worth noting that in the case of applying for the right to the so-called early retirement pension, the cessation of agricultural activity, pursuant to Article 6 point 3 of the above mentioned $\mathrm{Act}^{13}$, was a prerequisite for establishing the right to that benefit, which meant that it was required to dispose of the ownership of an agricultural holding. In addition, a farmer applying for early retirement was not a pensioner, since the decision to grant that benefit was constitutive in nature and not, like a decision establishing entitlement to a pension on reaching retirement age, declaratory in nature. Therefore, a person who ceased agricultural activity in connection with applying for early retirement and for that purpose leased an agricultural holding with the simultaneous entry of that agreement in the land and buildings register did not meet. The conditions referred to in Article 28(4)(1) of the above mentioned Act on social insurance for farmers. In this case, Article 38(1) of that Act should have been cited as the basis for the lease agreement. Having all that in mind one may additionally state, interpreting literally Article 28 (4) (1) of the above mentioned Act on

13. Within the meaning of Article 6(3) of the above-mentioned Act on Social Insurance of Farmers, agricultural activity means activity within the scope of plant or animal production, including gardening, horticulture, beekeeping and fishing. 
social insurance of farmers, that the legislator is silent about the actual conducting of agricultural activity in the issue of pension benefits and leaves the issue of conducting or not conducting agricultural activity aside as irrelevant for the payment of the supplementary part of the benefit. Consequently, the main purpose of this provision is the generational replacement of farm managers and not the cessation of farming activities by those entitled to a pension. Consequently, it would be possible to put forward a thesis that the regulation contained in Article 38(1) of the Act on social insurance of farmers refers to being subject to social insurance of farmers, which was defined by the legislator by the use of the phrase "it shall be presumed in determining whether a person is subject to insurance..." in this provision. Indicating the differences between these provisions, it can be stated that according to Article 38(1) of the Act on Social Insurance of Farmers, it does not matter who the lessor is, i.e. it can be an active farmer as well as a pensioner. Thus, the differences between the lease contract referred to in Article 38(1) of the above-mentioned Law and the lease contract referred to in Article 28(4)(1) of the above-mentioned Law, for which specific solutions have been laid down, conditioning the possibility of payment of the supplementary part of agricultural pensions, and whose aim is that the land of pensioners should pass into the hands of new farmers able to carry out agricultural activity effectively, and not the mere fact of ceasing to carry out such activity.

The justification of the thesis about the different nature and the need to distinguish between lease agreements is further confirmed by $\$ 11$ paragraph 1 point 2 of the Regulation of the Minister of Regional Development and Construction of 29 March 2001 on land and building registration ${ }^{14}$, according to which the land and buildings register includes data on land that is subject to lease agreements, and on tenants of these lands, reported to the register in connection with the provisions of article 28 paragraph 4 point 1 , article 38 point 1 and article 117 of the Act of 20 December 1990 on social insurance for farmers. The subject wording of this provision was given by the Ordinance of the Minister of Administration and Digitisation of 29 November 2013 amending the Ordinance on the land and buildings register ${ }^{15}$. Until this change, the wording of $\$ 11(1)(2)$ of the regulation on the land and buildings register was limited in such a way that the register contained data on persons and organisational units that administer land under lease agreements, hereinafter referred to as "tenants", reported in the register pursuant to art. 28(4)(3) of the Act

14. Obwieszczenie Ministra Inwestycji i Rozwoju z 3 stycznia 2019 r. w sprawie ogłoszenia jednolitego tekstu rozporządzenia Ministra Rozwoju Regionalnego i Budownictwa w sprawie ewidencji gruntów i budynków, Dz. U. 2019 poz. 393.

15. Rozporządzenie Ministra Administracji i Cyfryzacji z 29 listopada 2013 r. zmieniające rozporządzenie w sprawie ewidencji gruntów i budynków, Dz. U. 2013 poz. 1551. 
of 20 December 1990 on social insurance for farmers. In the justification of the above-mentioned project of amending the regulation regarding the register of land and buildings it was stated that "The proposed amendment to $\$ 11 \mathrm{sec}$. 1 clause 2 ( $\$ 1$ clause 7 letter a of the project of the regulation) results from the fact that this provision, in its current wording, did not take into account all legal regulations that make the acquisition of respective rights by the owner of leased land dependent on the disclosure of the lease agreement regarding this land in the register".

It follows that in the Regulation ${ }^{16}$ on land and building registration distinguishes between three independent grounds for concluding a tenancy agreement, which are concluded in accordance with the provisions on social insurance for farmers and are shown in the land and building register. Consequently, assuming that under Article 38(1) of the above mentioned Law on social insurance for farmers the lessor may be a person who wishes to demonstrate that he has ceased agricultural activity and thus be excluded from the obligation to be covered by social insurance for farmers, he should be entitled not to have the flat-rate income from his agricultural holding included in the income required for the acquisition of family allowances, even though he is not an agricultural pensioner. A lease agreement concluded pursuant to Article 38(1) of the above Act, in accordance with the provision in question of the Regulation on the registration of land and buildings, is registered in the land and buildings register without any additional requirements as to the entities between which it is concluded. Thus there is no justification as to why such an interpretation should not accompany the application of the provisions on family benefits, namely Article 5(8a)(1) of that Act.

At this point, it is worth noting that an analogous issue occurs under the provisions of the Act of 11 February 2016 on state aid in raising children ${ }^{17}$. In that Act, too, we were dealing with the interpretation, well established in case law $^{18}$, formed against the background of an identically formulated provision of Article 7 Section 6 as in Article 5 Section 8 a of the Family Benefits Act of 28 November $2003^{19}$, where the lease agreement, pursuant to the provisions of the social insurance scheme for

16. As a side note, it should be noted that this regulation is valid until July 31,2021 . This is due to the fact that as of 31 July 2020, the Act of 16 April 2020 on amending the acts - Geodetic and Cartographic Law and certain other acts, Journal of Laws 2020, item 782 (Ustawa z 16 kwietnia 2020 r. o zmianie ustaw - Prawo geodezyjne i kartograficzne oraz niektórych innych ustaw, Dz. U. 2020 poz. 782) came into force. The act in question introduced changes in the provisions on social insurance of farmers. Until the introduction of the amendment in question, in accordance with the provisions of the social insurance of farmers, the agreements referred to in Article 28(4)(1) and Article 38(1) were registered in the land and buildings register, and after the amendment they are confirmed by the head of the village which is competent as to the location of the subject of the lease.

17. Ustawa z 24 czerwca 2021 r. o zmianie niektórych ustaw związanych ze świadczeniami na rzecz rodziny, Dz. U. 2021 poz. 1162.

18. Wyrok Wojewódzkiego Sądu Administracyjnego w Lublinie z 27 września 2018 r., II SA/Lu 683/17.

19. Dz. U. 2020 poz. 111 ze zm. 
farmers, is concluded exclusively between operators, under which the lessor is always the pensioner. In the above context, the sentence of the Voivodship Administrative Court in Poznan is worth noting ${ }^{20}$, in which the court did not share the view that only a farm lease agreement, in which the lessor is a pensioner, exempts from the obligation to take income (calculated in a lump sum) into account when determining family income in the proceedings for granting child care benefit. The provision of Article 7(6)(1) of the Act on State Aid for Raising Children, analysed by the court in the wording "leased on the basis of a lease agreement concluded in accordance with the provisions of the social insurance of farmers", does not, in the court's view, indicate that the reference refers to the subject party of the agreement indicated in the provisions of the social insurance of farmers. For it expressly refers to the definition of a contract and not to the person who may enter into such a contract. As the court noted, a party to such an agreement is certainly a member of the family whose income is determined for purposes of the child-rearing benefit. The remainder of the provision refers to the leasing out of part or all of an agricultural holding owned by the family. Therefore, there is no justification for holding that only a pensioner can be a lessor. The Act on Social Insurance of Farmers does not contain a separate definition of such an agreement. However, its necessary elements are provided for in this law. The fact that Article 28 (4) (1) of the Act on Social Insurance for Farmers indicates a pensioner as a lessor does not mean that in the light of Article 7 (6) (1) of the Act on State Aid for Child Rearing, only a pensioner is to be a lessor. Since Article 28(4) of the Act on Social Insurance of Farmers regulates situations in which a pensioner is deemed to have ceased agricultural activity, it is clear that the pensioner is indicated. This does not mean, however, that in the light of the cited Article 7 (6) (1) of the Act on State Aid for Child Rearing, only a pensioner concluding a tenancy agreement in writing for 10 years with a stranger can be exempted from including income from a farm leased in this way. It should be noted that Article 7. 6. 1 of the Act on State Aid for Raising Children refers to the provisions of the social insurance of farmers, and not only to Article 28. 4 of the Act on Social Insurance of Farmers. That law does not regulate only the situation of pensioners, nor is there any justification, even in view of the addressees of child-raising benefits, for referring only to pensioners to the extent under consideration. With regard to the issue of presumption of agricultural activity and cessation of such activity, the Act on social insurance of farmers is not limited only to pensioners. Section 32 of the Act appropriately directs that section 28(4) be applied to an adult (the provision relates to the payment of a survivor's pension). For this reason alone, limiting the interpretation

20. Wyrok Wojewódzkiego Sądu Administracyjnego w Poznaniu z 18 lipca 2019 r., II SA/Po 186/19. 
of the provision of Article 7(6)(1) of the Act on State Aid for Child Rearing to the content of Article 28(4) of the Act on Social Insurance of Farmers is not justified. It is also worth noting the content of Article 38 of the Act on social insurance of farmers, according to which the presumption of conducting agricultural activity on agricultural land includes the owner of the land or the lessee of such land, if the lease is registered in the register of land and buildings. In the Act on social insurance for farmers, art. 117 states that lease agreements concluded pursuant to art. 2. 6. b of the Act referred to in art. 122, i.e. the repealed Act of 14 December 1982 on social insurance for individual farmers and members of their families (Dz. U. 1989 no. 24, item 133) are subject to registration in the land and buildings register. Pursuant to Article 2(6)(b) of the Law of 14 December 1982, this is the lease of land forming part of an agricultural holding to a person who is not the farmer's spouse, descendant or descendant's spouse and who is not in common household with the farmer under a lease agreement concluded for a period of at least 10 years. According to the court, since the applicant proved that the agreement she concluded meets these conditions and constitutes an agreement referred to in Article 7(1)(6) of the Act on State Aid for Child Rearing concluded pursuant to the provisions of the Act on Social Insurance for Farmers, it is not the income from the leased farm, but the lease rent that should be included in the income when determining the income criterion.

Thus, the court found in the judgment that the competent authorities, by adding the income from an agricultural holding, had breached Article 7(6)(1) of the Act on State Aid for Child Rearing and therefore the decisions had to be annulled. When establishing the income criterion, taking into account the interpretation of Article 7(6)(1) of the Act on State aid for the upbringing of children set out in this judgment, this should be done taking into account the lease rent and not the flat-rate farm income. This is in line with the approach already presented, which has not yet gained widespread acceptance ${ }^{21}$, but they should be pointed out as appropriate, so that those who should count on receiving the child-rearing benefits due can obtain them in accordance with the current legislation, which is still largely not properly interpreted. While it is true that the court used additional arguments in the judgment at issue, beyond those in the position presented in the article, it should be considered that they are not contradictory, but merely provide additional rationale for the accuracy of the view discussed in the article.

21. E. Nasternak, Ustalanie dochodu dla celów związanych ze świadczeniami rodzinnymi w stosunku do osób, które wydzierżawiły gospodarstwa rolne, "Ubezpieczenia w Rolnictwie. Materiały i Studia" 2017, nr 62. 


\section{Summary}

In view of the above, it is justified to change the interpretation of the provisions in question on family benefits so as to avoid that a person who is not a pensioner but who owns an agricultural holding which has been leased out pursuant to Article 38(1) of the Law on Social Security for Farmers is added to the lump-sum income from the leased agricultural holding when applying for family benefits. The reason for this is that, having regard to, for example, the above-mentioned Regulation on land and building registration, the conclusion of a lease agreement on agricultural land in accordance with the provisions on social insurance for farmers - does not apply only to pensioners. Consequently, lump-sum income from an agricultural holding leased out by a person who is not a pensioner should not be added to the income earned by this person from other sources which determine the acquisition of, for example, a family allowance, which is one of the benefits granted under the provisions of the above mentioned Act on Family Benefits. Alternatively, as indicated above, the lease rent in the amount resulting from the lease contract should be added to income, which would make it possible to grant family benefits on the basis of a properly established personal, family, income and asset situation of individuals or families.

\section{Bibliography}

Jończyk J., Świadczenia rodzinne [in:] Prawo zabezpieczenia społecznego, Zakamycze 2006.

Kamińska I., Matarewicz J., Rozbicka-Ostrowska M., Komentarz do spraw administracyjnych. Wybrane Zagadnienia, WK 2015 r., Lex 256303.

Konstytucja RP z 2 kwietnia 1997 r., Dz. U. 2006 nr 200 poz. 1471 oraz nr 114 poz. 946.

Maciejko W., Świadczenia rodzinne. Komentarz, C.H. Beck 2014.

Nasternak E., Ustalanie dochodu dla celów związanych ze świadczeniami rodzinnymi w stosunku do osób, które wydzierżawiły gospodarstwa rolne, “Ubezpieczenia w Rolnictwie. Materiały i Studia” 2017, nr 62.

Orzeczenie Naczelnego Sądu Administracyjnego z 27 października 2006 r., sygn. akt I OSK 601/06.

Orzeczenie Naczelnego Sądu Administracyjnego z 5 listopada 2008 r., sygn. akt I OSK 1930/07 i I OSK 1929/07.

Orzeczenie Naczelnego Sądu Administracyjnego z 23 czerwca 2009 r., sygn. akt OSK 1290/08.

Orzeczenie Naczelnego Sądu Administracyjnego z 3 września 2009 r., sygn. akt I OSK 3/9.

Orzeczenie Naczelnego Sądu Administracyjnego z 18 lutego 2010 r., sygn. akt I OSK 1425/09.

Orzeczenie Naczelnego Sądu Administracyjnego z 3 lutego 2011 r., sygn. akt. I OSK 1712/10.

Orzeczenie Naczelnego Sądu Administracyjnego z 9 marca 2011 r., sygn. akt I OSK 1922/10. 


\section{Opinion critical of the prevailing view the jurisprudence of the courts as regards}

Orzeczenie Naczelnego Sądu Administracyjnego z 4 lutego 2015 r., sygn. akt I OSK 1906/13.

Rozporządzenie Ministra Rozwoju Regionalnego i Budownictwa z 29 marca 2001 r. w sprawie ewidencji gruntów i budynków, Dz. U. 2019 poz. 393.

Rozporządzenie Ministra Administracji i Cyfryzacji z 29 listopada 2013 r. zmieniające rozporządzenie w sprawie ewidencji gruntów i budynków, Dz. U. 2013 poz. 1551.

Sierpowska I., Świadczenia rodzinne [in:] Prawo pomocy społecznej, Oficyna 2008.

Sierpowska I., Ustawa o pomocy społecznej. Komentarz, Kraków, Wolters Kluwer 2007.

Ustawa z 14 grudnia 1982 r. o ubezpieczeniu społecznym rolników indywidualnych i członków ich rodzin, Dz. U. 1998 poz. 133 i 190 oraz Dz. U. 1990 poz. 90 i 198.

Ustawa z 20 grudnia 1990 r. o ubezpieczeniu społecznym rolników, Dz. U. 2021 poz. 266.

Ustawa z 28 listopada 2003 r. o świadczeniach rodzinnych, Dz. U. 2020 poz. 111 ze zm.

Ustawa z 11 lutego 2016 r. o pomocy państwa w wychowaniu dzieci, Dz. U. 2021 poz. 1162.

Wyrok NSA z 14 grudnia 2007 r., sygn. akt I OSK 321/07.

Wyrok NSA z 15 grudnia 2008 r., sygn. akt I OSK 50/08.

Wyrok Wojewódzkiego Sądu Administracyjnego w Lublinie z 27 września 2018 r., II SA/Lu 683/17.

Wyrok Wojewódzkiego Sądu Administracyjnego w Poznaniu z 18 lipca 2019 r., II SA/Po 186/19.

Wyrok Wojewódzkiego Sądu Administracyjnego w Warszawie z 19 marca 2009 r., I SA/Wa 50/09, LEX nr 533503. 